Voix et Images

voixetimages

\title{
II.2 Équipes de direction de la BJ/NBJ
}

Volume 10, numéro 2, hiver 1985

La barre du jour / La nouvelle barre du jour

URI : https://id.erudit.org/iderudit/013870ar

DOI : https://doi.org/10.7202/013870ar

Aller au sommaire du numéro

Éditeur(s)

Université du Québec à Montréal

ISSN

0318-9201 (imprimé)

1705-933X (numérique)

Découvrir la revue

Citer cet article

(1985). II.2 Équipes de direction de la BJ/NBJ. Voix et Images, 10(2), 17-17.

https://doi.org/10.7202/013870ar d'utilisation que vous pouvez consulter en ligne.

https://apropos.erudit.org/fr/usagers/politique-dutilisation/ 


\section{II.2 Équipes de direction de la BJ/NBJ}

Les noms sont reproduits dans l'ordre où ils apparaissent à la page qui sert de fiche signalétique à la revue: membres de l'équipe de direction, adresse de la revue, distributeur, etc. Dès qu'un changement apparaît dans une équipe, le tableau qui suit se déplace vers une colonne supplémentaire: ainsi, les onze colonnes relatives aux équipes de direction de la $\mathrm{BJ}$, et les quatre de la NBJ.

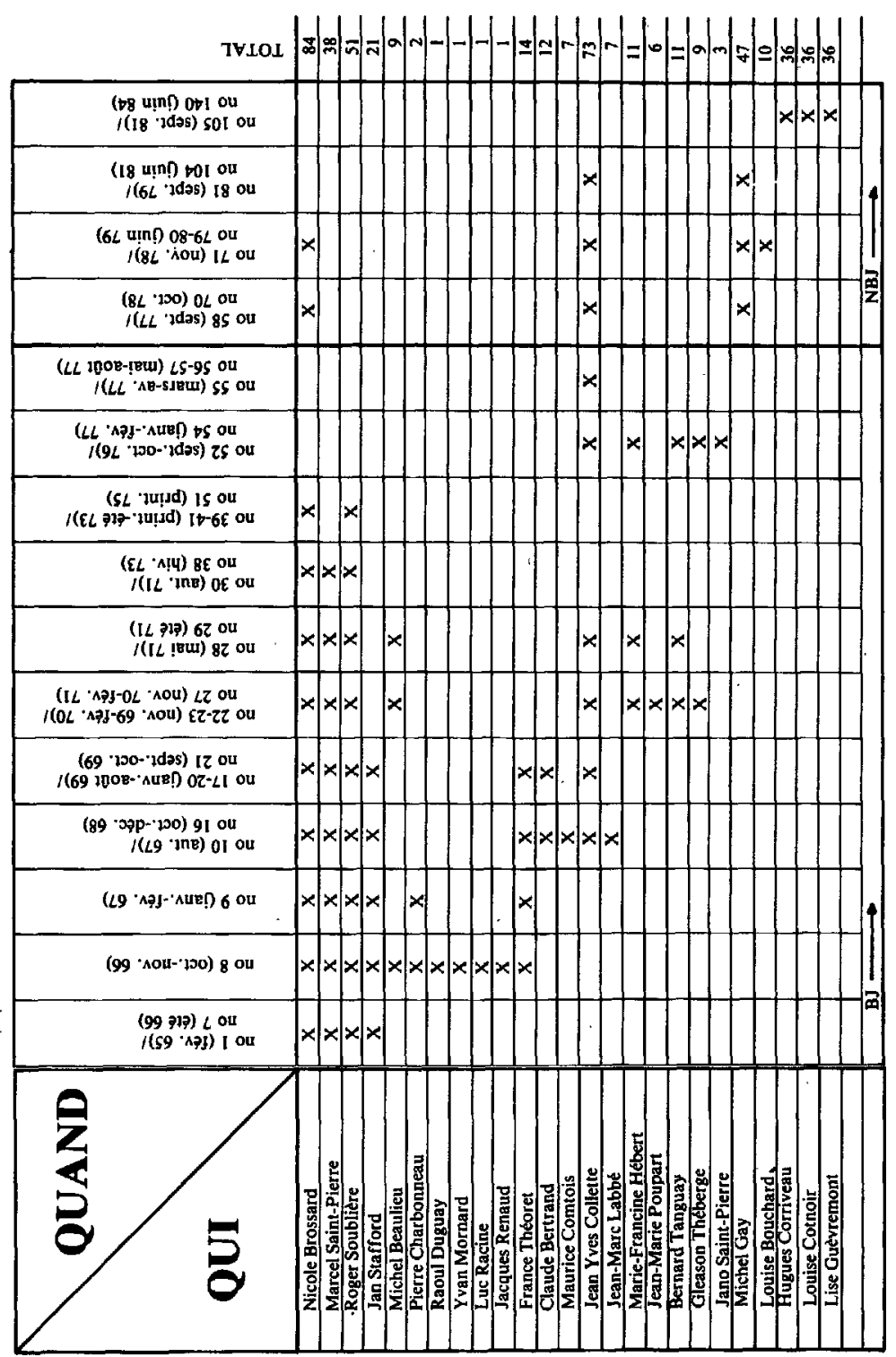

